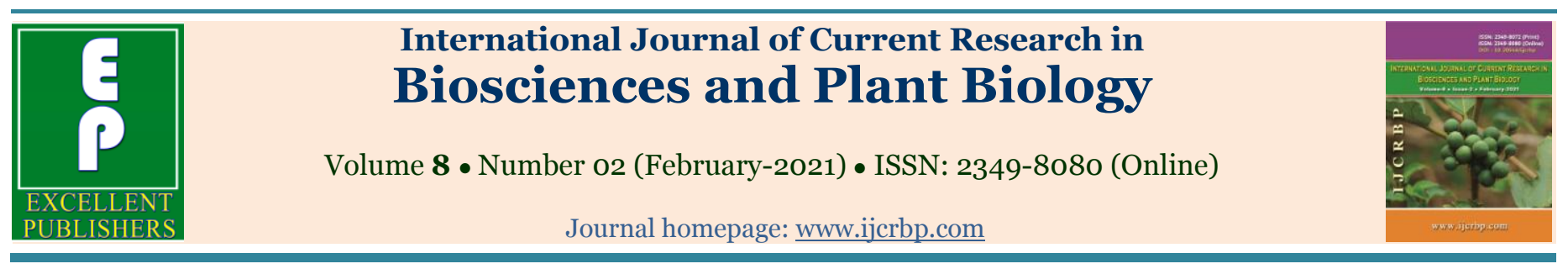

\title{
Population distribution, conservation status and vulnerability of Ternstroemia cameroonensis Cheek. in the Lebialem Highlands, Cameroon
}

\author{
Francoline Jong Nkemnkeng ${ }^{1}{ }^{1}$, Mendi Grace Anjah ${ }^{1}$, Walter Ndam Tacham ${ }^{2}$, Christiana \\ Ngyete Nyikob Mbogue ${ }^{1}$, Junior Baudoin Wouokoue Taffo ${ }^{3}$, Victor-François Nguetsop ${ }^{1}$
}

\author{
${ }^{I}$ Department of Plant biology, Faculty of Sciences, University of Dschang, P. O. Box 67, Dschang, Cameroon \\ ${ }^{2}$ Department of Biological Sciences, Faculty of Sciences, University of Bamenda, Bamenda, Cameroon, P.O Box 39 Bambili \\ ${ }^{3}$ Department of Biological Sciences, Faculty of Sciences, University of Maroua, P.O Box 814 Maroua, Cameroon
}

*Corresponding author; e-mail: tebafranc24@ yahoo.com; +237-675552330

\section{Article Info}

Keywords:

Critically endangered species

Lebialem Highlands

Rare species

Vulnerability,

Ternstroemia

cameroonensis

Abstract

The study was conducted in the Lebialem Highlands with the aim to assess the population distribution, sustainability and conservation status of Ternstroemia cameroonensis in its natural habitat. A total of 25 circular plots of $10 \mathrm{~m}$ diameter were established around T. cameroonensis and all species as well as threat to their sustainability evaluated. Data were collected, entered into excel and various percentages calculated while diameter at breast height of $T$. cameroonensis and three companion species where analysed in STATGRAPHICS XVII.II and the mean separated. The results revealed that $T$. cameroonensis is found in six localities, mostly between $1500 \mathrm{~m}$ to $2500 \mathrm{~m}$ above sea level. The three companion species were Aguaria saliciflora, Cyathea camerooniana and Draceana mannii. The most exploitable individuals were at Agocham (64\%) while the least at Fossimondi (25\%). The highest percentage of dead stems was recorded in Magha (42.85). Among the exploited stems, 33.33\% showed a completely dead crown, whereas $10 \%$ regular and healthy. The main part of the species exploited $\mathrm{w}$ the bark $(100 \%)$ and in case the stem gets dry it is exploited as fuel wood. T. cameroonensis was shown to be more vulnerable in Montane forests (2.8) than gallery forest (2.6).
\end{abstract}

\section{Introduction}

Biodiversity loss presents a crucial problem for conservationists and ecologists. The biodiversity of Tropical African countries represents a very important part of the global biological diversity (Myers et al., 2000; Brooks et al., 2001). The knowledge of the biological diversity in tropical Africa began with the works of the first colonial administrators and continued with the first botanists till present time. Besides South
Africa, Cameroon is the most biologically rich country known to date on the African continent (Sunderland et al., 2003). According to Letouzey (1968), floristic research in Cameroon began in earnest when Gustav Mann investigated Mount Cameroon for the first time in December 1861. Later, several botanists travelled to Cameroon and collected material which was deposited in European Herbaria, particularly (Holmgren et al., 1990). The specific richness of vascular plant species can be estimated at between 8,700 and 9,500 species 
(Onana, 2011) amongst which 7,385 are native and 534 are introduced, of which 185 are naturalized while 349 are cultivated. They are repartitioned into 248 families and 1884 genera. A significant number of the species in this flora are threatened, a more reduced part undergoes pressures due to the human activities on the ecosystems that shelter them or directly on them. Other species are naturally rare or even threatened because living in fragile biotopes with fewer populations. In this last group of habitats, the edges of rivers, mangrove, the swamp forests and mountains appear as appropriate sites for choice (Adou Yao et al., 2010).

Although Ternstroemia cameroonensis is reported in this flora (Cheek et al., 2017), its distribution, management and ecological status within the region is poorly documented; hence offsetting the elaboration of a strategy for its sustainable management. A previous study reported that Ternstroemia cameroonensis is critically endangered (IUCN, 2012) and was first documented as a rare montane tree species by Letouzey (1977) restricted to these highlands. It is among the most vulnerable medicinal tree species exploited showing lack of regeneration and an erratic stand structure. In order to promote the species valorisation in Cameroon, there is a need to document the actual products and uses of the species, as well as the exploitation practices and vulnerability status of exploited stands. The population structure of a plant is very vital for its sustainability.

The Lebialem Highlands provides diverse ecological functions as it plays a vital role for local populations as it serves as a watershed, provide firewood, wood for construction, medicine and food plants. This forest is also part of the spiritual and cultural heritage at Cameroon level (Gardner et al., 2001). This area is naturally isolated from other forested areas within the country due to its mountainous characteristics. Montane forest ecosystems of Cameroon are considered zones of high biodiversity concentration in the Africa continent globally (Burgess et al., 2007). They are sites with the highest endemism and biodiversity hotspot (Cheek et al., 2000).

These ecosystems forms part of Mounts Bamboutos which provide valuable goods and services to local people in the region and also an important watershed lodging the tributaries of Manyu River that drain into the cross river. The ecosystem is a centre of high endemism for many taxa (plants, amphibians, mammals and birds) and its destruction could lead to the local extinction of globally threatened biodiversity, watershed destruction and degradation of livelihood systems, property and lives. The area is highly fragmented due to its ruggedness, topography, drainage patterns and also by the progression of farm lands, repeated fires, increasing wood harvesting (Gardner et al., 2001; Armenteras et al., 2021) unregulated exploitation of forest products and proximity to the indigenous population (Stewart, 2009; Sheng-Lan et al., 2020). This investigation is thus aimed at characterizing the population structure and vulnerability Ternstroemia cameroonensis in the Lebialem Highlands of Cameroon.

\section{Materials and methods}

\section{Study site}

This study was carried out in the Lebialem Highlands located in the North Eastern part of the Southwest Region of Cameroon between latitudes $5^{\circ} 38 \mathrm{~N}$ and $5^{\circ} 43$ $\mathrm{N}$ and longitude $9^{\circ} 58 \mathrm{E}$ and $10^{\circ} 27 \mathrm{E}$ (Nkembi, 2004). The climate of this region is that of the Cameroon mountain range characterized by high winds and low sunshine. The average daily temperature varies very much with season and ranges from $17^{\circ} \mathrm{C}$ to $32^{\circ} \mathrm{C}$ (Zogning et al., 2007). The area is between 1000-2800 $\mathrm{m}$ above sea level and annual rainfall is $2222 \mathrm{~mm}$.

\section{Forest inventory}

This was carried out from April 2018 to December 2020 in nine localities namely, Agocham, Fomenji, Awoh, Magha, Agong, Fonenge, Fotang, Mbaranka and Fossimondi. In each locality, discussions were held with the local population if Ternstroemia cameroonensis is present and the possible locations. A walk in the park was effected in the possible locations to ascertain if the plant is present and plot established. This constituted circular plots of $10 \mathrm{~m}$ diameter established with respect to Ternstroemia cameroonensis. This consisted of two inventory techniques:

The itinerant inventory (Kouamé, 1998; Adou Yao et al., 2007) to test if Ternstroemia cameroonensis is still present on site. If present, the number of individuals was counted and circular plots placed around each plant to record all the species present and to count the seedlings $(\leq 10 \mathrm{~cm} \mathrm{dbh})$, the saplings $(\leq 30 \mathrm{~cm} \mathrm{dbh})$ and mature individuals $(\geq 30 \mathrm{~cm})$ of Ternstroemia cameroonensis. The threats that can affect the species 
and its habitat were noted to discuss the conservation status of the species. This was applied in each of the localities chosen. The following evaluations were made after the survey; the diameter at breast height of Ternstroemia cameroonensis and three associated species were measured, floristic diversity such as frequency, abundance, species richness, evenness and diversity indices.

\section{Vulnerability assessment}

The method of circular plots (total: $78.5 \mathrm{~m}^{2}$ ) was used to assess the sustainability of exploitation being applied on
Ternstroemia cameroonensis. Factors evaluated consisted of physical and environmental vulnerability. The twenty-five circular plots of $10 \mathrm{~m}$ in diameter were set from 1500 to $2500 \mathrm{~m}$ a.s.l. around Ternstroemia cameroonensis. Physical vulnerability parameters (Table 1) used in the assessment constituted of 4 criteria and 3 level scales as described by Betti (2001), Tsabang (2008), and Kemeuze (2010). Such criteria included: gathering method, morphology, the vegetative organ harvested, as well as the number of individuals at a given site. The crown health status of the trees was also evaluated based on the percentage of drying out $(0,20$, 40, 60, 80 and 100\% (dead individual) (Fig. 1).

Table 1. Parameters assessed for the estimation of the vulnerability index (VI) in the various land use systems considered for the study.

\begin{tabular}{llll}
\hline \multirow{2}{*}{ Parameters } & Vulnerability scales & & \\
\cline { 2 - 4 } & Weak (Scale 1) & Medium (Scale 2) & High (Scale 3) \\
\hline Life form & Herbs & Shrub & Tree \\
Popularity & Not popular $(\mathrm{F}<20 \%)$ & Less popular $(20 \%<\mathrm{F}<60 \%)$ & Popular (F>60\%) \\
Part collected & Leaves & Fruits & Bark, roots and wood \\
Collection methods & Harvesting of the leaves & Harvesting of the seeds & Debarking and felling \\
\hline Scall
\end{tabular}

Scale 1: low vulnerability (high chance of surviving after harvest), Scale 2: average vulnerability; and 3: highly vulnerable after exploitation (Betti, 2001).

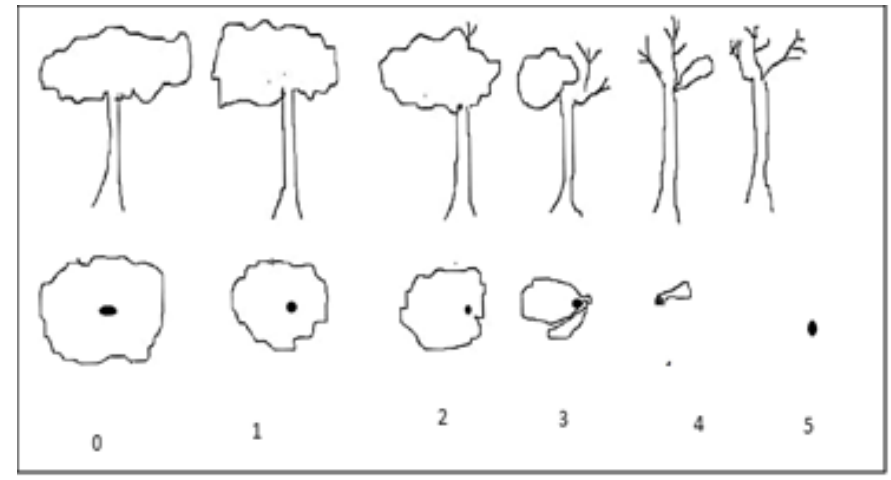

Fig. 1: Classification of the health status of the tree crown as a function of the state of their crown. Attribution: Modified from Cunningham, 2001. The status of the crown is thereafter related to the exploitation intensity of the tree (Cunningham, 2001): (0): Perfect, complete circle; excellent size and development, wide, symmetrical and generally circular in plan; (1): Good irregular circle; slightly asymmetrical with some dead branch tips (silviculturally satisfactory" to forester); (2): Tolerable: half of the crown; markedly asymmetrical, some die-back; (3): Poor: extensive die-back, leaves form less than half of the original crown size; (4): Very poor: few leaves on the branches; badly damaged, unlikely to survive; (5): Dead.

The values from 1 to 3 were assigned to each of the parameters used for the assessment, which affected the survival of the species within a particular land use system. The overall vulnerability index (VI) was estimated by calculating the average of the values obtained for all the 4 parameters considered in Table 1, with: $1<\mathrm{VI} \leq 2$, meaning that the plant is not vulnerable and the natural potential is still quite appropriate for exploitation; $2<\mathrm{VI} \leq 2.5$ indicates that the plant is becoming vulnerable in the given environment; VI $\geq 2.5$ shows that the plant is highly vulnerable and need sustainable management strategies.

Evaluation of health status of the tree crown was adapted from the methodology developed by Cunningham (2001). The method is based on the possible effect of the bark harvesting on the reduction of the tree crown, starting from the entire crown for an unexploited and healthy stem (0) to complete death of the crown for an overexploited and dead tree (5) (Fig. 1).

Environmental vulnerability was evaluated based land use, slope and other disturbance like bushfire (Table 2). These parameters were evaluated on a scale of 1,2 and 3 which entail weak, medium and high vulnerability respectively. 
Table 2. Environmental vulnerability of Ternstroemia cameroonensis in the Lebialem Highlands.

\begin{tabular}{llll}
\hline \multirow{2}{*}{ Parameters } & Vulnerability scales & & High (Scale 3) \\
\cline { 2 - 4 } & Weak (Scale 1) & Medium (Scale 2) & Very steep slope \\
\hline Slope & Absence or gentle slope & Steep slope & Intensive \\
Land use & Absent & Moderate & Vast \\
Bushfire & Absent & Moderate & Very steep slope \\
Slope & Absence or gentle slope & Steep slope & \\
\hline
\end{tabular}

Scale 1: low vulnerability (high chance of surviving after harvest), Scale 2: average vulnerability; and 3: highly vulnerable after exploitation (Betti, 2001).

\section{Data analysis}

Data collected were entered into excel and subjected into various analysis. Mapping was performed using the software Excel and ArcGIS 10.6 while the diameter at breast height of Ternstroemia cameroonensis was subjected to analysis of variance using STATGRAPHICS XVII.II and mean separated. The density and basal area of Ternstroemia cameroonensis and three companion species were equally computed and histogram and pie chart established to demonstrate preferential altitudes and health status of the crown respectively. Characteristics of stands as well as well as environmental vulnerability of the different sites were also evaluated.

\section{Results}

\section{Distribution of Ternstroemia cameroonensis within the Lebialem Highlands}

Ternstroemia cameroonensis was discovered in six out of the nine localities visited, that is Agocham, Fomenji, Awoh, Magha, Agong and Fossimondi (Fig. 2). Stem density varied from locality to the other and with altitude. Many were found in Agocham (18 stems) followed by Awoh (8 stems) and least in Fossimondi (4 stems). Most of the individuals found were between altitude $1500 \mathrm{~m}$ and $2500 \mathrm{~m}$ with most stems between 1500 and $2000 \mathrm{~m}$ above sea level (Fig. 3).

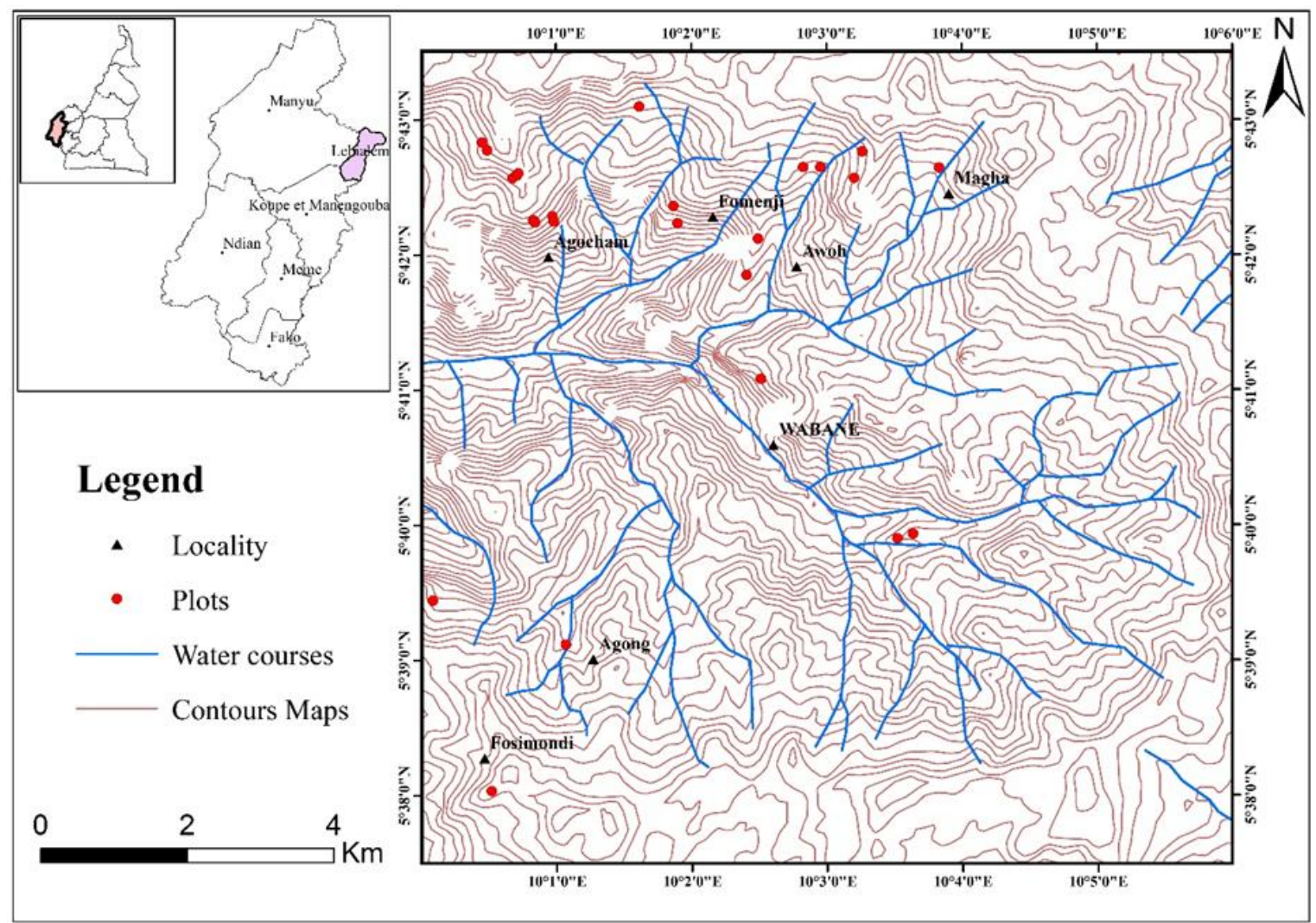

Fig. 2: Map of localities Agocham, Fomenji, Awoh, Magha, Agong and Fossimondi showing the sites of occurrences of Ternstroemia cameroonenesis in the Lebialem Highlands Cameroon (drawn using ArcGIS 10.6). 


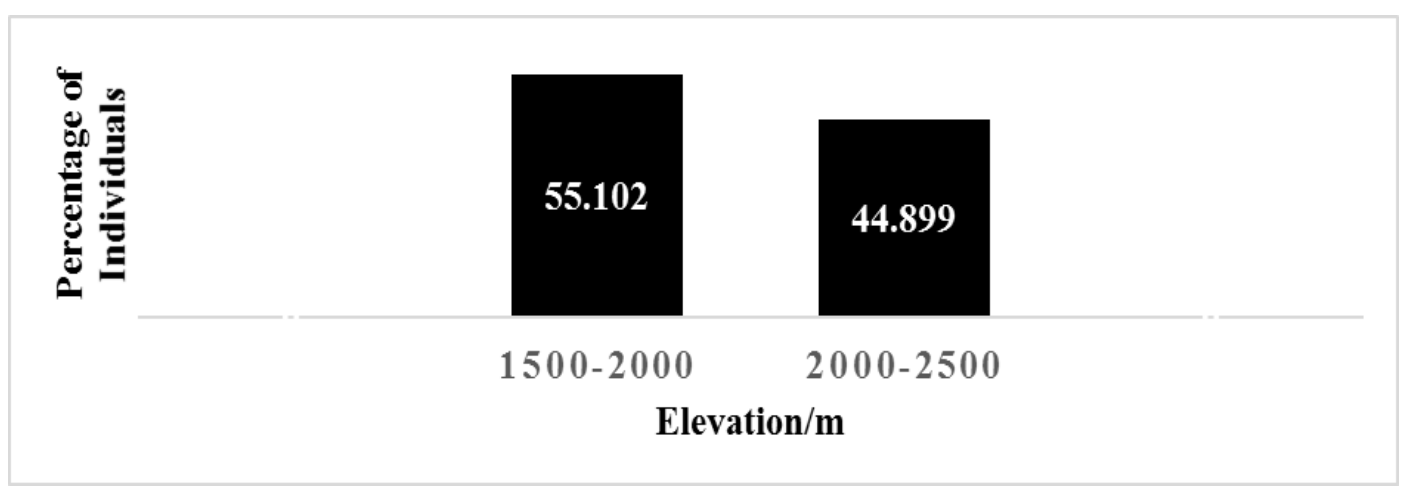

Fig. 3: Percentage distribution of Ternstroemia cameroonensis based on elevation.

Vegetation of occurrence sites and companion species

The sites of occurrence are covered by dry montane forest and gallery forest which is more fragmented. There were some prominent species in the higher, medium and lower stratum. At the higher stratum (about $2000 \mathrm{~m}$ ) there were species such as Aguaria salicifolia, Albizia adianthifolia, Eucalyptus saligna with some rare individuals like Noxia congesta, Albezia lebbeck, Allablackia floribunda and Prunus africana. The medium stratum consists of Cyathea camerooniana, Rauvolfia vomitoria, Phoenix dactylifera, Erica mannii, Harungana madagascariensis, Carapa grandiflora, Gnidia glauca, Bridelia micrantha and Macaranga ocidentalis. While the lower stratum consisted species like Psychotria dalzelli, Psychotria elata, Satureja montana, Venonia titanophylla, Draceana arborea, Draceana mannii, Adenocarpus mannii, Datura metel and extensive herbaceous stratum made up of species such as Brillantaisia nitens, Erygium foetidum, Mimulopsis solmsii, Eremomstax speciosa, Echinops gracilis, Palisota bracteosa, Desmodium uncinatum, Hyparrhenia cymbaria, Pennisetum purpureum and young individuals of the species mentioned above. The inventory in the 10 circular plots allowed recording 79 species on an area of $785.4 \mathrm{~m}^{2}$. Despite these plants in the different strata, some were frequent and abundant around Ternstroemia cameroonensis such as Aguaria salicifolia, Cyathea camerooniana and Draceana mannii. The density of the main associated species varying between 167 and 925 individuals/ha more than that of Ternstroemia cameroonensis (Table 3). However, their mean DBH and basal area was less.

Table 3. Comparison of densities, mean DBH and basal areas of Ternstroemia cameroonensis and three companion species on the site.

\begin{tabular}{llllll}
\hline Species & Surface (ha) & No. of individuals & Density $(\mathbf{s t e m} / \mathbf{h a})$ & Mean DBH/cm & Basal area $\left(\mathbf{m}^{\mathbf{2}} / \mathbf{h a}\right)$ \\
\hline Ternstroemia cameroonensis & 16.33 & 49 & 3.00 & $13 \pm 2.63^{\mathrm{c}}$ & 6.973 \\
Aguaria salicifolia & 0.521 & 32 & 61.40 & $8.50 \pm 1.85^{\mathrm{b}}$ & 5.010 \\
Cyathea camerooniana & 0.451 & 68 & 150.77 & $7.60 \pm 2.54^{\mathrm{b}}$ & 2.776 \\
Draceana mannii & 0.124 & 115 & 927.40 & $0.90 \pm 0.43^{\mathrm{a}}$ & 0.0428 \\
\hline
\end{tabular}

\section{Structural parameters}

\section{Stem density of Ternstroemia cameroonensis in various localities:}

Stem densities of Ternstroemia cameroonensis varied in the six localities (Agocham, Fomenji, Awoh, Magha, Agong and Fossimondi). The plant was found at several sites in Agocham and Awoh with stem density of 18 and 8 respectively while Fossimondi had the least that is 4 (Table 4).
Exploitation potential and vulnerability status of Ternstroemia cameroonensis in Lebialem Highlands

The largest number of exploitable stems was observed at Awoh and Agocham localities while Fossimondi showed least percentage of exploited individuals. The percentage of dead trees after exploitation was significant and higher at Magha (42.8\%) compared to other sites. The vulnerability indices calculated for the two main production systems of Ternstroemia cameroonensis in the Lebialem Highlands (Table 5). 
The values were found to be high for parameters such as popularity (3), parts used (3) and harvesting methods (3) in both montane forest and gallery forest. However, the vulnerability values were average for availability parameter in both montane forest and gallery forest ecosystem. The morphological parameter showed an average value for gallery forest ecosystem and high for montane forest ecosystem. On the basis of these values for vulnerability parameters, the vulnerability index was estimated at 2.8 in montane forest and 2.6 in the gallery forest. The vulnerability index of the plant in both environments was above 2 (Table 6). This showed that the natural environment and human activities are a serious threat to the survival and wellbeing of the plant.

Table 4. Characteristics of Ternstroemia cameroonensis stands in the sampled villages around the Lebialem Highlands.

\begin{tabular}{lllllll}
\hline Locality & No. of plots & No. stems & No. exploitable stems & Exploitable stems \% & No. dead stems & \% dead stem \\
\hline Agocham & 9 & 18 & 11 & 64.70 & 1 & 5.88 \\
Fomenji & 3 & 5 & 3 & 60 & 0 & 0 \\
Awoh & 6 & 8 & 5 & 62.5 & 2 & 25 \\
Magha & 4 & 7 & 3 & 42.85 & 3 & 42.85 \\
Agong & 2 & 7 & 3 & 42.85 & 1 & 14.28 \\
Fossimondi & 1 & 4 & 1 & 25 & 0 & 0 \\
\hline
\end{tabular}

Table 5. Vulnerability Indices (VI) for montane forest and gallery forest stands of Ternstroemia cameroonensis in the Lebialem Highlands, Cameroon.

\begin{tabular}{lllllll}
\hline Ecosystem Type & Morphology & Availability & Popularity & Part collected & Method of collection & VI \\
\hline Montane forest & 3 & 2 & 3 & 3 & 3 & 2.8 \\
Gallery forest & 3 & 1 & 3 & 3 & 3 & 2.6 \\
\hline
\end{tabular}

Table 6. Environment vulnerability indices of Ternstroemia cameroonensis in the Lebialem Highlands.

\begin{tabular}{lllll}
\hline Ecosystem Type & Slope & Land use & Bushfire & VI \\
\hline Montane forest & 3 & 2 & 2 & 2.33 \\
Gallery forest & 3 & 3 & 2 & 2.66 \\
\hline
\end{tabular}

\section{Health status of the crown and vitality of exploited trees}

A greater proportion of exploited trees showing "poor" crown $(26.67 \%)$ followed by those with very poor crown (20\%) while some were completely dead after stripping (13.33\%). Stems where exploitation was not intense still had perfect crown (10\%) (Fig. 4). Fig. 5 and Fig. 6 show the completely dry and battered stems of Ternstroemia cameroonensis and bark completely stripped in the Lebialem Highlands.

\section{Discussion}

Most individuals of Ternstroemia cameroonensis found in the various localities in the Lebialem Highlands were between $1500 \mathrm{~m}$ and $2500 \mathrm{~m}$ above sea level with a majority between 1500 and $2000 \mathrm{~m}$ that was 55\%. This could be the preferential sites of occurrence of the species or equally less anthropogenic activities due to the rugged nature of the slopes within this range. Most intensive agricultural activities were concentrated in the higher altitude that is above $2000 \mathrm{~m}$. These areas had higher impact of bushfire (Armenteras et al., 2021) and landslides which could be a deterrent to the population and survival of this species.

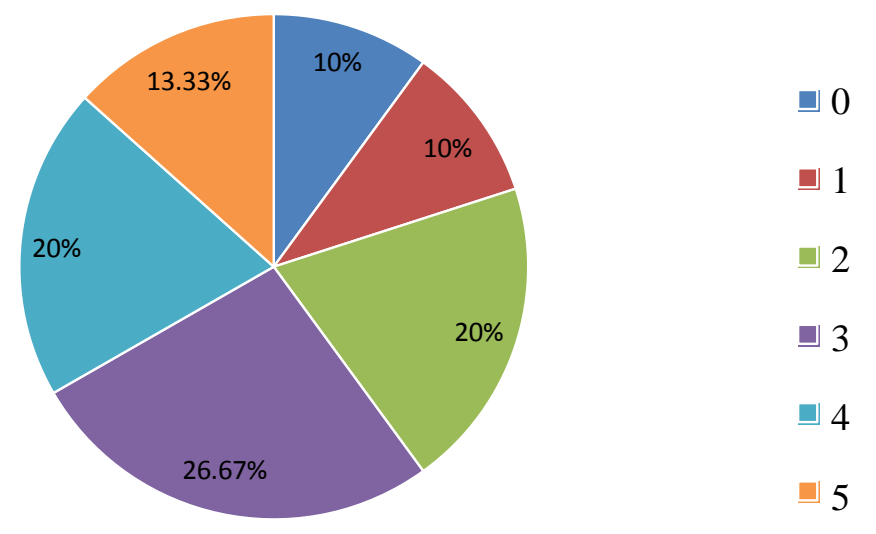

Legend: $0=0 \%, 1=20 \%, 2=40 \%, 3=60 \%, 4=80 \%, 5=100 \%$.

Fig. 4: Vitality status of exploited trees of Ternstroemia cameroonensis in the Lebialem Highlands as function of their percentage of dryness. The scale from 0 to 5 represents the degree of dryness or reduction of the crown as per the chart described by Cunningham (2001). 

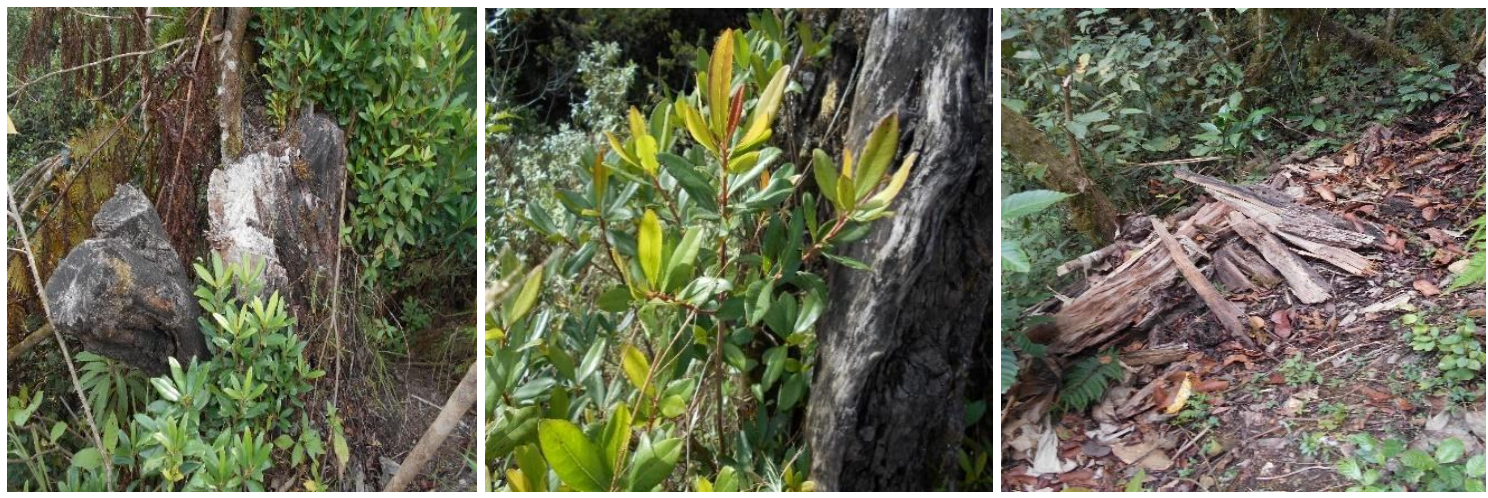

Fig. 6: Completely dry and battered stems of Ternstroemia cameroonensis in the Lebialem Highlands.
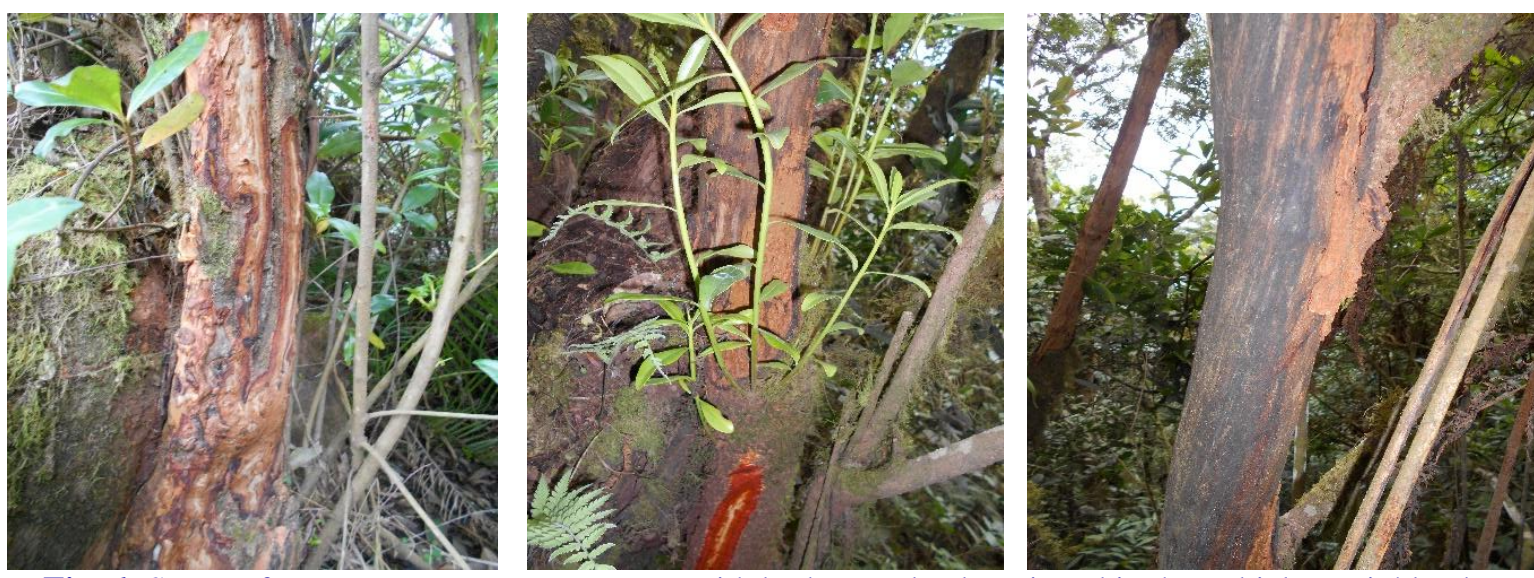

Fig. 6: Stems of Ternstroemia cameroonensis with bark completely stripped in the Lebialem Highlands.

Flowering and fruiting were greater among species of higher altitude may be due to more exposure and availability of sunlight. Some species of lower altitude had no fruits while others few fruits since they were shaded by taller emergent species thus posing a serious threat to the survival of the species. Seedlings and sapling were less than $5 \%$ of the total number of individuals in the study area. This could also be as a result of the microsites of the species which does not support seed germination and establishment. As fruits are carried by torrents of fast flowing streams in the gullies to unfavourable habitat, eaten by rodents or birds and seeds destroyed or carried to unfavourable habitats (Tchiengue et al., 2015). Seeds may also have difficulty to germinate as in other species of the family (Xavier and Carmen, 2016).

The number of stems varied considerably from one village to another as well as the intensity of exploitation. The high number of exploited stems in the sites of Agocham, Awoh and Fomenji are due to their proximity, accessibility and awareness (Sheng-Lan et al., 2020). The closer the sites are to the villages and the easier it is to access the trees, the more they are prone to exploitation of their bark. This result is also reflected in the number of dead trees observed in Magha. According to the values of vulnerability indices obtained in this study, Ternstroemia cameroonensis is highly vulnerable in the study zone. Apart from "availability", all the vulnerability parameters assessed scored high vulnerability values (scale 3) though the only part exploited was stem bark. A similar result was obtained by Ayena et al., (2016) on Pterocarpus santaloides in South Benin which was found to be vulnerable due to the multiplicity of plant organs exploited and used. Avana-Tientcheu et al. (2018) had contrary result following a study on the vulnerability assessment of Gnidia glauca exploitation in the community forest of Kilum-Ijim, North Western Cameroon. The montane forest stand of Terntroemia cameroonensis is more vulnerable to exploitation than those in the gallery forest. The terrain in gallery forest was more difficult 
compared to montane forest. Open and easy accessibility of resources are known to favour overexploitation; therefore, increasing vulnerability if strong regulations are not put in place (Cunningham et al., 2016; Guedje et al., 2016).

Again, low proportion of exploited trees showing "perfect" crown could be that the method of exploitation by entirely stripping stem bark has a detrimental effect on bark reconstitution after harvesting. This result is contrary to those of Guedje et al. (2016) on Garcinia lucida, Nkeng et al. (2009) and Cunningham et al. (2016) on Prunus africana which revealed that the capacity of these species for bark reconstitution after harvesting and therefore their survival after exploitation depend on the exploitation techniques and debarking intensity. This species is however unable to resist stress caused by intensive exploitation of bark, thus appropriate technique of bark exploitation is necessary for potential and durable harvest.

\section{Conclusion}

Terntroemia cameroonensis is reported in six localities in the Lebialem Highlands between $1500 \mathrm{~m}$ to $2500 \mathrm{~m}$ above sea level. Individuals found are sparsely distributed and this altitudinal range can be considered as the endemic zone to this plant. Among the threats to this species are the slash and burn farming methods, bushfire, rugged nature of the slopes and landslides. Intrinsic characteristics such as lack of fruits on many trees and seedlings also contributed to threaten its survival.

Due to the unsustainable harvesting techniques, there is low proportion of living and exploitable individuals that is worth harvesting for community livelihood. Only stem bark of Ternstroemia cameroonensis is mostly harvested for medicinal use within and without the local communities. In case the stem gets dry, it harvested for fuel wood. It can thus be concluded from this study that Ternstroemia cameroonensis population in the Lebialem Highland is highly vulnerable and sustainable harvesting technique should be reconsidered for exploitation by population, provided that a more appropriate debarking method is developed, tested and handed on to local harvesters. The species is also critically endangered and need to be protected. However, sensitization and conservation program initiated through tree preservation and protection on- farm should be encouraged to ensure sustainability and future supply of the resources.

\section{Conflict of interest statement}

Authors declare that they have no conflict of interest.

\section{Acknowledgement}

We wish to acknowledge the support of URBOA (Unité de Recherché en Botanique Appliqué) of the Department of Plant Biology, University of Dschang. We also appreciate the Regional Delegation of Forestry and Wildlife for the North West for their materials and technical support.

\section{References}

Adou Yao, C. Y., Aké-Assi, E., Ipou Ipou, J., 2010. Proposition d'inscription de Monanthotaxis capea (Annonaceae) de Côte d'Ivoire sur la Liste Rouge de l'UICN. In: van der Burgt, X., van der Maesen, J., Onana,J.-M. (Eds), Systématique et Conservation des Plantes Africaines. Royal Botanic Gardens, Kew. pp.445-449.

Adou Yao, C. Y., Denguéadhé, K. T. S., Kouamé, D., N'Guessan, K. E., 2007. Diversité etdistribution des ligneux dans le Sud du Parc National de Taï (PNT), Côte d'Ivoire. Agron. Afr., 19(2): 113-122.

Avana-Tientcheu, M.L., Momo, S. M. C., Kamga, Y.B., Nguetsop V. F., 2018. Vulnerability assessment of (Gnidia glauca Thymelaeaceae) exploitation, traditional uses and domestication potential in the community forest of Kilum-Ijim, North Western Cameroon. J. Ecol. Natural Environ., 10(8): 182191.

Ayena, A. C., Agassounon, D. T. M., Assogbadjo, A., Adoukonou-Sagbadja, H., Mensah, G. A., Agbangla, C., Ahanhanzo, C., 2016. Usages et vulnerabilité de Pterocarpus santalinoides L'her. Ex De (Papillionoidae), une plante Utilisée dans le traitement des Gastro-Enterites dans le Sud du Benin. Eur. Scient. J., 12(6): 218-231.

Betti, J. L., 2001. Usages traditionnels et vulnérabilités des plantes médicinales dans la réserve de Dja et dans le marché. Resource separation in a NapoAmazonian gamebird community. In: Brooks, D.M., Gonzalez, F. (Eds). Biology and Conservation of Cracids in the New Millenium. Misc. Publ., 2: 213-225. Houston Museum of Natural Sciences, Houston, Texas. 
Armenteras, D., Meza, M. C., Gonzalez, T. M., Oliveras, I., Balch, J. K., Retana, J., 2021. Fire threatens the diversity and structure of tropical gallery forest. Ecosphere, 12(1): 1-16.

Burgess, N. D., Balmford, A., Cordeiro, N. J., Fjeldså, J., Küper, W., Rahbek, C., Sanderson, E. W., Scharlemann, J. P. W., Sommer, J. H., Williams, P. H., 2007. Correlations among species distributions, human density and human infrastructure across the high biodiversity tropical mountains of Africa. Biol. Conserv., 134: 164-177.

Cheek, M., Onana, J. M., Pollard, B. J., 2000. The Plants of Mount Oku and the Ijim Ridge, Cameroon, A Conservation Checklist. Royal Botanic Garden, Kew, 211p.

Cheek, M., Tchiengue, B., Tacham, W. N., 2017. Ternstroemia cameroonensis (Ternstroemiaceae), a new medicinally important species of montane tree, nearly extinct in the Highlands of Cameroon. Blumea, 62: 53-57.

Cunningham, A. B., 2001. Applied Ethnobotany. People Wild Plant Use and Conservation.WWF, UNESCO, KEW, Earthscan, Condon and Streling. 450p.

Cunningham, A., Anoncho, V. F., Sunderland, T., 2016. Power, policy and the Prunus africana bark trade, 1972-2015. J. Ethnopharmacol., 178: 323-333.

Gardner, A. A., Demarco, J., Asanga, C. A., 2001. A conservation partnership community forestry at Kilum-Ijim, Cameroon. Rural Development Forestry Network, 25: 9-16.

Guedje, N. M., Tadjouteu, F., Tchamou, N., Ndoye, O., 2017. The use of traditional ecological knowledge in sustainable use and management of plant resource through a community-based and participatory assessment. Int. J. Biol. Chem. Sci. 11(4): 1611-1626.

Guedje, N. M., Tchamou, N., Lejoly, J., 2016. Tree response to bark harvest: the case of a medicinal species, Garcinia lucida, as source of raw materials for plant-based drug development. J. Appl. Biosci., 99: 9476-9471.

Holmgren, P. K., Holmgren, N. H., Barnett, L. C., 1990. Index Herbariorum Part I: Herbaria of the World, Regnum Vegetabile 120, $8^{\text {th }}$ Edn. New York Botanical Garden, New York.

IUCN, 2012. IUCN Red List categories and criteria: Version 3.1. $2^{\text {nd }}$ Edn. Gland, Switzerland and Cambridge, UK: IUCN. Available from: http://www.iucnredlist.org/ [accessed: Jan. 2017].

Kemeuzé, V. A, 2010. Diversité et Ethnoecologie du genre Combretum dans les régions semi-arides du
Cameroun. Thèse Master, Université de Dschang, Cameroun. 70p.

Kouamé, N. F., 1998. Influence de l'exploitation forestière sur la végétation et la flore de la forêt classée du Haut Sassandra (Centre-ouest de la Cote d'Ivoire). Thèse de Doctorat $3^{\text {ème }}$ cycle. Université de Cocody Abidjan. 228p.

Letouzey, R., 1968. Les botanistes au Cameroun. In: Aubréville, A. (Ed.). Flore du Cameroun 7. Muséum national d'Histoire naturelle, Paris. 110p.

Letouzey, R., 1977. Présence de Ternstroemia polypetala Melchior (Théacées) dans les Montagnes Camerounaises. Adansonia Série 2, Tome 17, fascicule 1: 5-10.

Myers, N., Mittermeier, R. A., Mittermeier, C. G., daFonseca, G. A. B., 2000. Biodiversity hotspots for conservation priorities. Nature, 403: 853-858.

Nkembi, L., 2004. Comparative study of community and government patrols in enhancing sustainable wildlife conservation in the Banyang-Mbo sanctuary, Cameroon. Tech. Rep., Ministry of Environment and Forestry, MINEF.

Nkeng, P. F., Ingram, V., Awono, A., Tientcheu, M. L. A., 2009. Assessment of Prunus africana bark exploitation methods and sustainable exploitation in the South West, North West and Adamaoua regions of Cameroon, in Project GCP/RAF/408/EC «Mobilisation et Renforcement des Capacités des Petites et Moyennes Entreprises impliquées dans les Filières des Produits Forestiers Non Ligneux en Afrique Centrale», CIFOR, Editor. FAO-CIFORSNV-World Agroforestry Center COMIFAC: Yaounde. 57p.

Onana, J. M., 2011. The vascular plants of Cameroon. A taxonomic check list with IUCN assessements. Flore du Cameroun 39. IRAD-National Herbarium of Cameroon, Yaoundé. 195p.

Stewart, K., 2009. Effects of bark harvest and other human activity on populations of the African cherry (Prunus africana) on Mount Oku, Cameroon. Forest Ecol. Manage., 258(7): 1121-1128.

Sunderland, T.C.H., Comiskey, J.A., Besong S., Mboh, H., Fonwebon J., Dione, M.A., 2003. Vegetation Assessment of Takamanda Forest Reserve, Cameroon, Smithsonian Institution.

Tsabang, N., 2008. Etude ethnobotanique des plantes à vertus antidiabétique et/ou antihypertensives au Cameroun. Thèse Doctorat $/ \mathrm{PhD}$, Université de Yaoundé I, 300p.

Xavier, C., Carmen, U. U., 2016. Ternstroemia washikiatii (Pentaphylacaceae): A new tree species 
from Eastern Ecuador. Harvard Papers Bot., 21(2): 337-339.

Sheng-Lan, Z., Ting-Ting, Gao, Y., Ouy, Z., Jia-Kuan, C., Li, B., Zhao, B., 2020. Effects of road age and distance on plant biodiversity: A case study in the Yellow River Delta of China. Plant Ecol., 212(7):
1213-1229.

Zogning, C. N., Tiafack, O., 2007. The catastrophic geomorphological processes in humid tropical Africa: A case study of the recent landslide disasters in Cameroon. Sediment. Geol., 199(1-2): 13-27.

\section{How to cite this article:}

Nkemnkeng, F. G., Anjah, M. G., Tacham, W. N., Nyikob Mbogue, C. N., Wouokoue Taffo, J. B., Nguetsop, W.-F., 2021. Population distribution, conservation status and vulnerability of Ternstroemia cameroonensis Cheek. in the Lebialem Highlands, Cameroon. Int. J. Curr. Res. Biosci. Plant Biol., 8(2): 1-10.

doi: https://doi.org/10.20546/ijcrbp.2021.802.001 